\title{
Pengaruh Motivasi dan Budaya Kerja Terhadap Kinerja Pegawai Di Kantor Sekertariat Daerah Kabupaten Enrekang
}

\author{
Hasdiah', Renil Darsa2, Muhammad Rais Rahmat ${ }^{3}$, Andi Astinah Adnan 4 \\ Magister Administrasi Publik, Sekolah Tinggi Ilmu Sosial dan Ilmu Politik Muhammadiyah Rappang \\ Enrekang, Sidenreng Rappang, Indonesia \\ 'renildarsa@gmal.com, ${ }^{2}$ mraisrahmat@yahoo.com, ${ }^{3}$ andi.astinah.adnan@gmail.com.
}

\begin{abstract}
Abstrak - Penelitian ini bertujuan; I) untuk mengetahui seberapa besar pengaruh motivasi kerja terhadap kinerja pegawai, 2) untuk mengetahui seberapa besar pengaruh budaya kerja terhadap kinerja pegawai, 3) untuk mengetahui seberapa besar pengaruh motivasi kerja dan budaya kerja terhadap kinerja pegawai di Sekretariat Daerah Kabupaten Enrekang. Lokasi penelitian pada Kantor Sekertari Daerah Kabupaten Enrekang. Penelitian ini dilaksanakan pada selama 2 bulan. Populasi diambil dari seluruh pegawai di Kantor Sekertariat Daerah Kabupaten Enrekang yang berjumlah 180 orang dan ditemukan sampel sebesar 64 orang. Dan tekhnik pengumpulan datanya adalah data primer dan data sekunder. Tekhnik analisis datanya yaitu deskriptif kuantitatif dengan bantuan program SPSS. Hasil penelitian menunjukkan bahwa motivasi mempunyai pengaruh signifikan terhadap kinerja pegawai, pengaruhnya sebesar $27 \%$ atau masuk dalam kategori kurang berpengaruh. Budaya kerja mempunyai pengaruh signifikan terhadap kinerja pegawai, pengaruhnya sebesar $65,6 \%$, semakin baik budaya kerja semakin baik pula kinerja pegawai. Pengaruh motivasi dan budaya kerja secara besama - sama berpengaruh signifikan terhadap kinerja pegawai. Pengaruh motivasi dan budaya kerja terhadap kinerja pegawai di Kantor Sekertariat Daerah Kabupaten Enrekang sebesar 70,3\%. Kesimpulan yaitu I). Motivasi berpengaruh signifikan terhadap kinerja pegawai yakni sebesar 0,19<0,2 dan 2) budaya kerja juga berpengaruh signifikan sebesar $0,00<0,2$ dan apabila diterapkan secara bersama - sama, maka akan berpengaruh signifikan ( 0,03 dan $0,00<0,2$ ) terhadap kinerja pegawai di Kantor Sekertariat Daerah Kabupaten Enrekang.
\end{abstract}

Kata kunci : motivasi kerja, budaya kerja dan kinerja pegawai

\section{PENDAHULUAN}

Undang-undang nomor 23 tahun 2014 tentang Pemerintahan Daerah memberikan warna khusus bagi penyelenggara pemerintahan di wilayah Kota/Kabupaten se Indonesia karena mempunyai implikasi langsung terhadap kemandirian atas pelaksanaan otonomi daerah oleh pemerintah daerah yang bersangkutan. Undang - Undang Aparatur Sipil Negara Nomor 5 Tahun 2014 sebagai pengganti dari Undang - Undang Nomor 8 Tahun 1974 tentang Pokok - Pokok Kepegawaian yang mengatur tentang Kode Etik dan Perilaku yang dijelaskan pada pasal 3 huruf $b$ bertujuan untuk menjaga martabat dan kehormatan Aparatur Sipil Negara., sedangkan kode etik dan kode perilaku sebagaimana dimaksud pada ayat (I) berisi pengaturan perilaku Aparatur Sipil Negara. Yaitu melaksanakan tugas dengan jujur, bertanggung jawab dan beritegritas tinggi, melaksanakan tugas dengan cermat dan disiplin, melayani dengan sikap hormat sopan dan tanpa tekanan, melaksanakan tugasnya sesuai dengan aturan perundang - undangan melaksanakan tugas sesuai dengan perintah atasan, menjaga kerahasiaan yang menyangkut kebijakan Negara, menggunakan kekayaan dan barang milik Negara secara bertanggung jawab, efektif dan efisien, menjaga agar tidak terjadi konflik kepentingan dalam melaksanakan tugasnya, memberikan informasi yang benar dan tidak menyesatkan kepada pihak lain yang memerlukan informasi, tidak menyalahgunakan informasi intern Negara, tugas, status, kekuasaan dan jabatannya untuk mendapatkan atau mencari keuntungan atau manfaat bagi diri sendiri atau untuk orang lain, memegang teguh nilai dasar Aparatur Sipil Negara dan selalu menjaga reputasi dan integritas Aparatur Sipil Negara, dan yang terakhir melaksanakan ketentuan peraturan perundang - undangan mengenai disiplin pegawai Aparatur Sipil Negara.. Disamping itu pada pasal 21 yang berbunyi : (I) Tuntutan akan kebutuhan yang semakin tinggi sebagai dampak krisis ekonomi global, kebutuhan hidup pegawai negeri sipil semakin tidak terpuaskan. $\mathrm{Hal}$ ini berakibat menurunnya motivasi dan budaya kerja pegawai dalam melaksanakan tugas. Pemberian kewenangan yang luas kepada pemerintah daerah membawa konsekuensi tertentu bagi daerah untuk menjalankan tugas dan tanggung jawabnya. Salah satu konsekuensinya yaitu daerah harus mampu membiayai semua kegiatan pemerintah dan pembangunan yang menjadi kewenangannya. Sejalan dengan hal ini Koswara 2000, menyatakan bahwa daerah otonomi harus memiliki kewenangan dan kemampuan untuk menggali sumber-sumber keuangan sendiri. Pengelolaan dan penggunaan keuangan sendiri harus cukup memadai untuk pembiayaan penyelenggaraan pemerintah dan pembangunan daerah.

Pada berbagai bidang khususnya kehidupan berorganisasi, faktor manusia merupakan masalah utama disetiap kegiatan yang ada didalamnya. Organisasi merupakan kesatuan sosial yang dikoordinasikan secara sadar dengan sebuah batasan 
yang reaktif dapat diidentifikasikan, bekerja secara terus menerus untuk mencapai tujuan, Robbins (2006). Semua tindakan yang diambil dalam setiap kegiatan diprakarsai dan dapat ditentukan oleh manusia yang menjadi anggota perusahaan. Perusahaan membutuhkan adanya faktor sumber daya manusia yang potensial baik pemimpin maupun karyawan pada pola tugas dan pengawasan yang merupakan penentu tercapainya tujuan perusahaan. Sumber daya manusia merupakan tokoh sentral dalam organisasi maupun perusahaan. Agar aktivitas manajemen berjalan dengan baik, perusahaan harus memiliki karyawan yang berpengetahuan dan berketerampilan tinggi serta usaha untuk mengelola perusahaan seoptimal mungkin sehingga kinerja karyawan meningkat. Menurut Budi Setyawan dan Waridin 2006, kinerja karyawan merupakan hasil atau prestasi kerja yang dinilai dari segi kualitas maupun kuantitas berdasarkan standar kerja yang ditentukan oleh pihak organisasi dan mendukung tercapainya organisasi. Organisasi yang baik adalah organisasi yang berusaha meningkatkan kemampuan sumber daya manusianya, karena hal tersebut merupakan faktor kunci untuk meningkatkan kinerja karyawan. Peningkatan kinerja karyawan akan membawa kemajuan pada perusahaan untuk dapat bertahan dalam suatu persaingan lingkungan bisnis yang tidak stabil. Oleh karena itu upaya-upaya untuk meningkatkan kinerja karyawan merupakan tantangan manajemen yang paling serius karena keberhasilan untuk mencapai tujuan dan kelangsungan hidup perusahaan/organisasi tergantung pada kualitas kinerja sumber daya manusia yang ada didalamnya.

Berdasarkan Peraturan Daerah Kabupaten Enrekang tentang Organisasi dan Tata Kerja Sekertariat Daerah Kabupaten Enrekang, diantaranya mengatur tentang Pemerintah Daerah, Tugas perbantuan dengan prinsip otonomi seluas-luasnya dalam sistem dan prinsip Negara Kesatuan Repubelik Indonesia (NKRI) sebagaimana yang dimaksud dalam UUD Tahun 1945, dimana juga menyebutkan berkaitan dengan otonomi daerah adalah hak, wewenang dan kewajiban daerah otonom untuk mengatur dan mengurus sendiri demi kepentingan masyarakat setempat menurut prakarsa sendiri berdasarkan aspirasi masyarakat sesuai dengan peraturan perundang-undangan. Kabupaten merupakan perangkat daerah yang dipimpin oleh seorang Bupati yang berkedudukan dibawah Gubernur. Untuk mendukung kelancaran penyelenggaraan urusan pemerintahan kabupaten maka bupati mempunyai tugas melaksanakan kewenangan pemerintahan yang dilimpahkan oleh Gubernur untuk menangani urusan otonomi daerah dan menyelengarakan tugas umum pemerintahan. Dalam observasi yang dilakukan penulis, total jumlah pegawai yang ada dikantor Sekertariat Daerah Kabupaten Enrekang yaitu sebanyak 180 orang, 53 diantaranya menduduki jabatan, 23 orang dengan pangkat Pembina, 4I orang dengan pangkat Penata, 35 orang sebagai Pengatur, dan tenaga kontrak dan sukarela sebanyak 81 orang. 99 orang sudah menduduki jabatan PNS di Kabupaten Enrekang. diketahui adanya kesenjangan atau kurangnya perhatian yang berkaitan dengan motivasi kerja, beberapa pegawai yang aktif terlibat dalam keikutsertaan pada tugas pekerjaan yang bersifat pelayanan masyarakat, atau dengan kata lain tidak pro aktif dalam melaksanakan tugasnya. Permasalahan yang berkaitan dengan budaya kerja yaitu adanya beberapa pegawai yang kurang bersahabat dengan pegawai lainya. Dalam melaksanakan tugasnya, ada beberapa pegawai yang kreatif dalam melaksanakan tugasnya, ada juga pegawai kurang bersemangat dalam bekerja sehingga selalu tertunda, dan kebanyakan pegawai tidak mengetahui apa yang dia harus lakukan. Permasalahan berikutnya yaitu yang berkaitan dengan kinerja pegawai, beberapa pegawai dalam menyelesaikan pekerjaan harus menunggu perintah dari pimpinan, sedangkan yang diinginkan adalah pegawai yang memiliki inisiatif dalam menyelesaikan tugas pekerjaan tidak menunggu perintah lebih lanjut dari pimpinan. Hal lain bahwa masih banyak pegawai yang sering terlambat dalam menyampaikan laporan. Mekanisme kepegawaian, pemerintahan, pembangunan yang belum optimal, target waktu penyelesaian laporan yang seharusnya disampaikan pada bulanan, triwulan bahkan semesteran masih terlambat, penyelesaian tugas pekerjaan dilaksanakan apabila pimpinan ada dikantor, $\mathrm{Hal}$ inilah yang sering membuat pekerjaan menjadi tertunda dan akan mengakibatkan pelayanan pemerintahan tidak optimal.

Kinerja pegawai dan tuntutan profesionalisme serta peningkatan mutu secara terus-menerus, menuntut semua karyawan/pegawai untuk selalu memperbaiki kinerja pada semua aspek. Hal ini tentunya didukug faktor motivasi, dan lingkungan kerja, dan memiliki kemampuan yang baik dari para pegawai yang ada. Dengan kinerja yang baik dan terorganisir akan dapat menambah kepercayaan masyarakat pada pelayanan yang diberikan oleh pemerintah. Berdasarkan uraian diatas, maka perlu dilakukan analisisa tentang "Pengaruh Motivasi Kerja dan Budaya Kerja Terhadap Kinerja Pegawai Lingkup Sekertariat Daerah Kabupaten Enrekang" dengan tujuan Untuk mengetahui seberapa besar pengaruh motivasi kerja terhadap kinerja pegawai negeri sipil lingkup Sekretariat Daerah Kabupaten Enrekang, Untuk mengetahui seberapa besar pengaruh budaya kerja terhadap kinerja pegawai negeri sipil lingkup Sekretariat Daerah Kabupaten Enrekang dan Untuk mengetahui seberapa besar pengaruh motivasi kerja dan budaya kerja tehadap kinerja pegawai lingkup Sekertariat Daerah Kabupaten Enrekang.

Istilah motivasi ( motivation) berasal dari bahasa latin yaitu movere yang berarti "menggerakkan" ( to move ) 'Motivasi adalah merupakan kekuatan yang berada dalam diri maupun yang berasal dari luar yang menjadi pendorong seorang pegawai untuk dapat melakukan pekerjaan dengan baik. Proses kerja akan optimal apabila pegawai memiliki motivasi kerja yang tinggi dan 
didukung dengan kemampuan, keterampilan, dan pengalam pegawai yang memadai. Meskipun memiliki kemampuan dan keahlian yang tinggi serta pengalaman yang cukup, seseorang tidak akan mencapai prestasi kerja terbaik apabila tidak ada motivasi kerja dalam diri orang tersebut. Sebaliknya meskipun seseorang memiliki motivasi yang sangat tinggi akan tetapi tidak didukung oleh kemampuan, keahlian dan pengalaman yang memadai tidak akan menghasilkan kinerja yang optimal. Namun demikian motivasi yang tinggi merupakan modal yang besar untuk mencapai sukses karena motivasi yang tinggi adalah setengah dari kesuksesan itu sendiri.

Menurut Malthis, 200I, motivasi merupakan hasrat didalam diri seseorang tersebut melakukan tindakan. Sedangkan Rivai (2004) berpendapat bahwa motivasi adalah serangkaian sikap dan nilai-nilai yang mempengaruhi individu untuk mencapai hal yang spesifik sesuai dengan tujuan individu. Motivasi adalah kesediaan melakukan usaha tingkat tinggi guna mencapai sasaran organisasi yang dikondisikan oleh kemampuan usaha tersebut memuaskan kebutuhan sejumlah individu (Robins dan Mary, 2005).

Selain itu Rivai (2004:457) menyampaikan pengertian motivasi adalah:(I)Sebagai suatu kondisi yang menggerakkan manusia ke arah suatu tujuan tertentu.(2) Suatu kehlian dalam mengarahkan karyawan dan perusahaan agar mau bekerja secara berhasil, sehingga keinginan karyawan dan tujuan perusahaan sekaligus tercapai.(3) Sebagai inisiasi dan pengarahan tingkah laku. Pelajaran motivasi sebenarnya merupakan pelajaran tingkah laku.(4) Sebagai energi untuk membangkitkan dorongan dalam diri.(5) Sebagai kondisi yang berpengaruh membangkitkan, mengarahkan dan memelihara perilaku yang berhubungan dengan lingkungan kerja.Motivasi kerja adalah sebagai langkah awal seseorang melakukan tindakan akibat kekurangan secara fisik dan psikis atau dengan kata lain adalah suatu dorongan kerja yang ditunjukkan untuk memenuhi tujuan tertentu.

Teori yang membahas tentang motivasi yaitu Teori Dua Faktor Hezberg. Menurutnya, factor factor seperti kebijakan, administrasi perusahaan, dan gaji yang memadai dalam suatu pekerjaan akan menetramkan karyawan. Bila factor - factor ini tidak memadai, maka orang -orang tidak akan terpuaskan ( Robbins.200I:I70 ) dalam http:/kuliah komunikasi.blogspot.co.id/2008/ I I/teori-motivasimcclellanddan teori dua factor Hezberg. Menurut hasil penelitian Hezberg ada 3 ( tiga ) hal penting yang harus diperhatikan dalam memotivasi bawahan ( Hasibuan 1990 : 176 ) yaitu :

a. Hal - hal yang mendorong karyawan adalah pekerjaan yang menantang yang mencakup perasaan berprestasi, bertanggung jawab, kemajuan, dapat menikmati pekerjaan itu sendiri dan adanya pengakuan atas semua itu.

b. Hal - hal yang mengecewakan karyawan adalah terutama pada factor yang bersifat embel - embel saja dalam pekerjaan, penerangan, istirahat dan lain sejenisnya.

c. Karyawan akan kecewa apabila peluang untuk berprestasi, terbatas. Mereka akan menjadi sensitif pada lingkungannya, serta mulai mencari - cari kesalahan.

Hezberg menyatakan bahwa orang dalam melaksanakan pekerjaannya dipengaruhi oleh dua faktor yang merupakan kebutuhan yaitu :

a. Maintenance Factors. Yaitu faktor - factor pemeliharaan yang berhubungan dengan hakekat manusia yang ingin memperoleh ketentraman badaniah. Kebutuhan kesehatan ini merupakan kebutuhan yang berlangsung terus - menerus karena kebutuhan ini akan kembali pada titik nol setelah dipenuhi.

b. Motivation Factors. Yaitu faktor motivator yang menyangkut kebutuhan psikologis seseorang yaitu perasaan sempurna dalam melakukan pekerjaan. Faktor motivasi ini berhubungan dengan penghargaan terhadap pribadi yang berkaitan langsung dengan pekerjaan.

Teori motivasi dengan pendekatan kebutuhan adalah teori dua faktor Hezberg, Mauser dan Synderman teori, sebagaimana yang dikutip oleh Hasbar mereka menyatakan bahwa ketidakpuasan kerja dan kepuasan kerja muncul dari dua set faktor yang terpisah, dan dua faktor tersebut dinamakan faktor yang membuat orang lain tidak puas dan faktor yang membuat orang menjadi puas.

Selanjutnyan, Budaya berasal dari bahasa Sansekerta yaitu buddhayah, yang merupakan bentuk jamak dari buddhi ( budi atau akal ), yang diartikan sebagai hal - hal yang berkaitan budi dan akal manusia. Dalam Bahasa Inggris kebudayaan disebut culture yang berasal dari Bahasa Latin Colere, yaitu mengolah atau mengerjakan. Budaya secara harafiah memiliki arti mengerjakan tanah, mengolah, memelihara ladang ( Soerjanto Poespowardojo:I993 ). Menurut Hartanto ( 2009 ) budaya dapat didefenisikan sebagai totalitas dari keyakinan, sikap, pola perilaku, kelembagaan, seni, tradisi dan produk pikiran manusia yang menjadi karakteristik dari suatu komunitas di dalam suatu lingkungan social. Budaya terbentuk dari berbagai symbol, ritual dan tata nilai, keyakinan, gagasan, makna serta pola perilaku yang bayak digunakan di dalam kehidupan sehari - hari. Lebih lanjut Hartanto ( 2009) mendefenisikan budaya kerja adalah suatu system makna yang terkait dengan kerja, pekerjaan dan interaksi kerja yang disepakati bersama dan digunakan di dalam kehidupan kerja sehari - hari.

L.W.Budiwinantara Melaksanakan budaya kerja tidak bisa dipisahkan dengan sumber daya manusia (SDM) itu sendiri, karena budaya kerja sangat erat kaitannya dengan sikap/perilaku dan paradigma berpikir manusia dalam menciptakan produktivitas kerja yang memadai. Maka sebagai aparatur negara setiap manusia yang berada/bekerja dalam instansiinstansi pemerintahan hendaknya mampu menciptakan budaya kerja yang kondusif, di mana hal tersebut 
menjadi tuntutan dasar dalam menciptakan kinerja modern (tepat guna). Dalam menciptakan sebuah sistem kerja untuk mewujudkan kinerja modern maka ada 3 faktor pendukung yang sangat penting, yaitu :

a. SDM (sumber daya manusia). Untuk menciptakan kinerja modern erat kaitannya dengan budaya kerja yang sedang berlaku sehingga peran serta setiap manusia didalamnya menjadi hal mutlak yang menentukan arah budaya kerja itu sendiri. Dalam hal ini setiap aparatur negara dalam menunaikan tugas-tugas kerja seharusnya memiliki nilai-nilai :

I) Disiplin. Dalam hal ini bukan hanya disiplin waktu yang menjadi perhatian setiap pekerja akan tetapi disiplin dalam menunaikan setiap tugas yang dibebankan kepadanya atau tanggung jawab kerjanya seharusnya bisa diselesaikan dengan baik. Berdisiplin secara kuantitas waktu kerja dan kualitas hasil kerja harus menjadi budaya kerja disetiap instansi-instansi pemerintahan.

2) Terampil/mampu menciptakan inovasi kerja. Dengan adanya tanggung jawab kerja berarti setiap pekerja juga diberikan keleluasaan untuk menunjukkan atau mengejewantahkan setiap keterampilan yang dimilikinya dalam menciptakan kualitas kerja yang inovatif sehingga terjadi pengembangan kerja yang berkualitas.

3) Berbasis pada Rasionalitas dan Kecerdasan Emosi. Penyaringan setiap tenaga kerja termasuk tenaga-tenaga kerja dalam instansiinstansi pemerintahan menjadi indikator bahwasanya kualitas sumber daya manusia menjadi syarat utama dalam menduduki setiap jabatan/posisi yang tersedia. Termasuk juga adanya pendidikan pelatihan-pelatihan yang dilaksanakan disetiap instansi menjadi penunjang untuk mewujudkan sumber daya manusia yang berbasis pada rasionalitas dan kecerdasan emosi. Sebagai aparatur negara kita harus dibekali dengan kematangan dan kecerdasan emosi dalam menghadapi setiap tantangan kerja.

4) Partisipatif/mampu membangun budaya kerja kelompok atau kerjasama yang baik, baik itu secara horizontal maupun vertikal. Untuk mewujudkan team work yang baik setiap pekerja seharusnya memiliki kemampuan partisipatif agar dalam penyelesaian setiap tanggung jawab terjadi sinkronisasi kerja yang efektif.

5) Tulus dan Ikhlas/mampu menempatkan atau memposisikan kerja sebagai tanggung jawab kemanusiaan sehingga terwujud motivasi kerja yang positif (tanpa pamrih). Hal ini menjadi sangat penting untuk terpenuhi karena harus diakui bahwasanya budaya kerja yang terjadi hampir di semua instansi pemerintahan banyak kehilangan nilai ini. Para pekerja tidak memandang setiap tanggung jawab kerja yang diberikan kepadanya mengandung nilai ibadah sehingga tidak mengherankan jika disetiap pelaksana kerja/tugas para pekerja tidak mampu menempatkan diri sebagai pelayan masyarakat yang menerapkan prinsip, standar, pola penyelenggaraan pelayanan publik, dan pemberian pelayanan prima kepada masyarakat yang merupakan perwujudan kewajiban aparatur pemerintah sebagai abdi masyarakat.

b. Imbalan/Materi. Tidak dapat dihindari bahwa setiap pekerja/pegawai memiliki hak untuk memperoleh imbalan dari setiap tanggung jawab kerja yang mereka emban. Dan oleh karena itu materi sebagai bentuk imbalan kerja menjadi hal penting untuk terpenuhi.

Oleh karena itu Karl Marx (dalam bukunya Das Kapital) menekankan bahwasanya untuk mewujudkan sistem perekonomian yang baik termasuk untuk mencapai sebuah hasil kerja yang masksimal maka setiap pekerja harus menerima imbalan/materi yang setimpal dari setiap hasil kerjanya, dimana hal ini juga menjadi motivasi terbesar bagi setiap pekerja untuk dapat menyelesaiakan setiap pekerjaannya secara maksimal. Hal ini yang kemudian menjadi rujukan banyak negara dalam menciptakan sebuah budaya kerja, yang kemudian mengarah pada penerapan budaya kapitalis tersebut. Dalam dunia bisnis/swasta budaya kerja kapitalis ini dapat dilihat dari pemberian "bonus" bagi para pekerja selain dari gaji pokok yang biasa mereka terima, dimana pemberian bonus ini sebagai bentuk imbalan dari hasil kerja mereka baik secara kuantitas maupun pencapaian kualitas hasil kerja sedangkan dalam instansi-instansi pemerintah biasa kita kenal dengan istilah honor yang belakangan ini kemudian menggelinding sebuah program sertifikasi (bagi Guru) dan tunjangan kinerja dibeberapa instansi pemerintahan dimana semua itu merupakan "penghasilan tambahan" sebagai buah dari hasil kerja yang dilakukan.

Selanjutnya, Kinerja adalah istilah yang popular di dalam manajemen yang mana istilah kinerja didefenisikan dengan istilah hasil kerja, prestasi kerja dan performance. Dalam kamus Bahasa Indonesia dikemukakan arti kinerja sebagai “ (I) sesuatu yang dicapai (2) prestasi yang diperlihatkan (3) kemampuan kerja “. Menurut Fattah ( 1999:19) dalam Khris Hartono, kinerja atau prestai kerja ( performance) diartikan sebagai “ ungkapan kemampuan yang didasari oleh pengetahuan, sikap keterampilan dan motivasi dalam menghasilkan sesuatu “. Sementara menurut Sedarmayanti (2001:50) bahwa “ kinerja merupakan terjemahan dari performance yang berarti prestasi kerja, pelaksanaan pencapaian kerja, untuk kerja atau penampilan kerja “. Sedangkan Samsudin (2005:159) menyebutkan bahwa “ kinerja adalah tingkat pelaksanaan tugas yang dapat dicapai seseorang, unit atau divisi dengan menggunakan kemampuan yang ada dan batasan - batasan yang telah ditetapkan untuk mencapai tujuan organisasi/perusahaan. Berdasarkan pengertian diatas dapat disimpulkan bahwa kinerja adalah penampilan yang melakukan ,menggambarkan 
dan menghasilkan sesuatu hal, baik yang bersifat fisik ataupun non fisik yang sesuai dengan petunjuk, fungsi dan tugasnya yang didasari oleh pengetahuan sikap , keterampilan dan motivasi.

Barry dalam Soehartono 2004, berpendapat kinerja karyawan adalah hasil kerja yang dapat dicapai oleh seseorang atau sekelompok orang dalam suatu organisasi, sesuai dengan wewenang dan tanggung jawab masing-masing, dalam rangka mencapai tujuan organisasi yang bersangkutan dengan secara legal, tidak melanggar hukum, dan sesuai dengan moral maupun etika. Menurut Mangkunegara, 2000, kinerja juga sepadan dengan prestasi kerja. Pengertian kinerja adalah hasil secara kualitas dan kuantitas yang dicapai oleh seorang karyawan dalam melaksanakan tugasnya sesuai dengan tanggung jawab yang diberikan.

Menurut Stephen P. Robbins, tingkat kinerja pegawai sangat tergantung kepada faktor-faktor yaitu, kemampuan pegawai itu sendiri seperti tingkat pendidikan, pengetahuan, pengalaman dimana denga tingkat kemampuan yang semakin tinggi akan mempunyai kinerja yang semakin tinggi pula. Faktor lain adalah motivasi kerja yaitu dorongan diri dalam seorang pegawai untuk melakukan suatu pekerjaan. Dengan motivasi kerja yang tinggi akan mempunyai kinerja yang tinggi dan sebaliknya. Sehingga dapat disimpulkan bahwa kedua faktor yaitu motivasi dan kemampuan mempunyai hubungan positif terhadap kinerja. Sedangkan indikator kinerja adalah kualitas, kuantitas, arahan dan dukungan, waktu yang dipakai, tanggung jawab, kerja sama, ketaatan.

Pengukuran kinerja merupakan suatu alat manajemen untuk meningkatkan kualitas pengambilan keputusan oleh para pimpinan. Sebenarnya pengukuran kinerja mempunyai makna ganda yaitu, pengukuran kinerja itu sendiri dan sebagai evaluasi kinerja. Untuk melakukan kedua hal tersebut terlebih dahulu harus ditentukan tujuan yang akan dicapai. Setelah program didesain termasuk penciptaan berbagai indikator kinerja atau keberhasilan pelaksanaan program sehingga dapat diukur tingkat pencapaian hasil. Pengukuran kinerja merupakan jembatan antara perencanaan strategis dengan akuntabilitas. Instansi pemerintah dapat dikatakan berhasil jika terdapat bukti-bukti atau indikator-indikator dalam pencapaian tugas organisasi publik. Tanpa adanya pengukuran kinerja sangat sulit dicari kebenaran yang logis, perencanaan yang jelas teroperasionalkan dan terstruktur diharapkan memberi pembenaran yang logis dan argumntatif yang memadai. Sedangkan menurut Henry Simamora 1987:485, maksud ditetapkan tujuan kinerja adalah menyusun sasaran yang berguna tidak hanya evaluasi kinerja pada akhir priode tetapi jugan untuk mengelola proses kerja selama priode tersebut.

\section{METODE PENELITIAN}

Jenis Penelitian yang dilakukan untuk mengolah dan menganalisis penelitian ini adalah penelitian metode deskriptif, populasi dalam hal ini adalah keseluruhan pegawai di Kantor Sekertariat Daerah Kabupaten Enrekang sebanyak 180 orang, sedangkan tekhnik pengambilan sampel yang dugunakan adalah nonprobability sampling dengan tekhnik penarikan dengan tingkat kesalahan $10 \%$, jadi jumlah sampel adalah 64 orang

Adapun tekhnik pengumpulan data yaitu wawancara, observasi, kuisioner, dan studi kepustakaan, sedangkan tekhnik analisis data yaitu analisis deskriptif, uji kualitas data, uji asumsi klasik, dan model regresi linear berganda. Dengan bantuan SPSS.

\section{HASIL DAN PEMBAHASAN}

Berdasarkan hasil penelitian dan pengujian yang telah diuraikan, maka diperoleh data bahwa ada pengaruh motivasi kerja dan budaya kerja terhadap kinerja pegawai di Sekertariat Daerah Kabupaten Enrekang. Adapun uraian tersebut sebagai berikut:

I. Pengaruh motivasi kerja terhadap kinerja pegawai (XI ke Y).

Berdasarkan uji statistik melalui spss diperoleh data bahwa, pengaruh motivasi kerja terhadap kinerja pegawai berpengaruh signifikan terhadap kinerja pegawai pada kantor Sekertariat Daerah Kabupaten Enrekang dengan nilai $t$ variabel motivasi kerja sebesar I,299 dengan tingkat signifikan $0,19<0,2$, berarti ada pengaruh yang signifikan variabel motivasi kerja terhadap kinerja pegawai dan hasil uji model summary pengaruh $X I$ terhadap $Y$ sebesar 27\%. Pentingya pemerintah untuk memperhatikan dan memberikan motivasi kepada pegawai dengan meliputi; I) banyaknya gaji yang diberikan kepada pegawai. 2) tingkat keamanan bagi pegawai. 3) kondisi ruangan pegawai. 4) kebijakan atau perintah yang diberikan kepada pegawai. 5) hubungan kerja pegawai dengan pegawai lainya.6) hubungan kerja antara pegawai dengan pimpinan. 7) tingkat keberhasilan pegawai. 8) rasa tanggung jawab pegawai. 9) pengembangan diri pegawai.

Selanjutnya, diantara 9 indikator motivasi kerja, yang paling besar pengaruhnya adalah indikator yang pertama yaitu upah atau gaji yang diberikan pegawai sebesar 95\%, itu berarti bahwa pemerintah melalui kantor Sekertariat Daerah Kabupaten Enrekang, harus memberikan gaji yang sesuai dengan kinerja pegawai, supaya dalam melakukan tugasnya dapat berjalan sesuai dengan ketentuan. Dan yang paling sedikit pengaruhnya adalah pengembangan diri pegawai yang persentasenya sebesar $73 \%$ saja pengaruhnya tetapi bukan berarti bahwa pegawai tidak harus memperhatikan pengembangan diri, karena sumber daya manusia harus mengembangkan diri supaya terciptanya kinerja yang lebih kreatif, inovatif, untuk mencapai hasil kerja yang lebih optimal.

2. Pengaruh budaya kerja terhadap kinerja pegawai.

Ivancevich, Lorenzi, Skinner \& Crosby dalam Ratminto dan Atik 2015, mendefinisikan budaya kerja sebagai suatu situasi kerja yang memungkinkan semua 
pegawai dapat melaksanakan semua pekerjaan dengan cara terbaik yang dapat dilakukanya. Dalam upaya untuk meningkatkan kinerja pegawai maka dalam hal ini adapun teori yang telah dipaparkan oleh Budiwinata, indikatornya adalah sebagai berikut; I) tingkat kedisiplinan pegawai. 2) keterampilan pegawai. 3) pendidikan dan pelatihan. 4) kerjasama pegawai. 5) pegawai memberikan pelayanan. 6) gaji yang diberikan pegawai. 7) pegawai dalam melaksanakan tugasnya. Masing-masing indikator tesebut diatas, yang paling berpengaruh adalah gaji yang diberikan kepada pegawai sebesar $88 \%$ Ini menunjukkan bahwa pemerintah seharusnya memberikan gaji/upah yang diberikan kepada pegawai sesuai dengan ketentuan yang berlaku. sedangkan yang paling sedikit adalah kedisiplinan pegawai sebesar $69 \%$, tetapi bukan berarti bahwa pemerintah tidak harus memperhatikan kedisiplinan para pegawai, karena kedisiplinan merupakan salah satu hal penting yang harus diperhatikan dalam melaksanakan tugas dan pekerjaanya.

Berdasarkan hasil uji statistik melalui SPSS diperoleh data bahwa budaya kerja berpengaruh signifikan terhadap kinerja pegawai dengan nilai thitung sebesar 10,886 dengan tingkat signifikan $(0,00<0,2)$, berarti ada pengaruh yang signifikan antara variabel budaya kerja terhadap kinerja pegawai dan hasil model summary besar pengaruh $X 2$ terhadap $Y$ sebesar $65,6 \%$.

3. Pengaruh motivasi dan budaya kerja terhadap kinerja pegawai di Kantor Sekertariat Daerah Kabupaten Enrekang (XI, X2 terhadap $Y$ ).

Berdasarkan olahan data SPSS model summary diperoleh data bahwa, motivasi dan budaya kerja terhadap kinerja pegawai di Kantor Sekertariat Daerah Kabupaten Enrekang adalah signifikan yaitu sebesar 0,03 dan $0,00<0,2$ dengan pengaruh sebesar 70,3\% masuk dalam kategori berpengaruh. Angka capaian presentase tersebut sebenarnya belum terlalu sesuai dengan apa yang diharapkan antara 76\% - 100\%, dengan kata lain bahwa apa yang diharapkan oleh pemerintah dan masyarakat terhadap kinerja pegawai masih sedikit dibawah standar yang seharusnya..

\section{KESIMPULAN}

Berdasarkan analisis hasil penelitian dan pembahasan, dapat disimpulkan sebagai berikut:

I. Pengaruh motivasi kerja mempunyai pengaruh yang signifikan terhadap kinerja pegawai dengan tingkat signifikan $0,19<0,2$ dengan pengaruh sebesar 27 \%. Makin tinggi motivasi yang diberikan pegawai, maka makin tinggi juga kinerja pegawai di Kantor Sekertariat Daerah Kabupaten Enrekang.

2. Budaya kerja pegawai mempunyai pengaruh signifikan terhadap kinerja pegawai di Kantor Sekertariat Daerah Kabupaten Enrekang dengan tingkat signifikan sebesar $0,000<0,2$ dengan pengaruh sebesar 65,6 \%. Semakin baik kultur budaya kerja semakin baik pula kinerja pegawai di Kantor Sekertariat Daerah Kabupaten Enrekang.
3. Pengaruh motivasi kerja bersama-sama dengan budaya kerja berpengaruh signifikan terhadap kinerja pegawai dengan tingkat signifikan ( 0,03 dan $0,00<02$ ) dengan pengaruh sebesar $70,3 \%$ di Kantor Sekertariat Daerah Kabupaten Enrekang, maka hal itu dapat meningkatkan kualitas kinerja pegawai yang baik pula.

\section{DAFTAR PUSTAKA}

[1] Ahmad Jamaluddin, 20II, perilaku birokrasi dan pengambilan keputusan, Badan Penerbit UNM Makassar.

[2] Ahmad Jamaluddin, 2015, metode penelitian administrasi publik, Gava Media, Yogyakarta

[3] Arep, Ishak, Henri Tanjung, 2003, manajemen sumber daya manusia, Universitas Trisakti, Jakarta.

[4] Hasibuan Malayu, 2003, mengenal dasar-dasar pengertian dan masalah, Bumi Aksara, Jakarta.

[5] Henry Simammora, 2004, manajemen sumber daya manusia, STIE YKPN, Yogyakarta.

[6] Keban, Y.T, 20I4, Enam dimensi strategis administrasi public, Gava Media, Yogyakarta.

[7] Komaruddin, 2006, pengembangan dan pelatihan (suatu pendekatan manajemen sumber daya manusia), Kappa Sigma, Bandung.

[8] Lberty Ahmad S. Ruky, 200I, sistem manajemen kinerja, Gramedia Pustaka Utama, Jakarta.

[9] Malthis, Robert L, Jakson dan John H., 2006, manajemen sumber daya manusia, Salemba Empat, Jakarta.

[10] Mangkunegara, 2003, perencanaan dan pengembangan sumber daya manusia, PT. Rafika Aditama, Bandung.

[II] Masrukhin dan Waridin, 2006, pengaruh motivasi kerja, kepuasan kerja, budaya organisasi dan kepemimpinan terhadap kinerja pegawai, Ekobis, Vol. 7, No. 2.

[12] Moh. Nasir, 2005, metode penelitian, Ghalia Indonesia, Jakarta.

[13] Mustafa, Delly,20I3. Birokrasi pemerintahan, Alfabeta, Bandung.

[14] Mustafa Hasbar,2012, menguak perilaku birokrasi, Badan Penerbit UNM, Makassar

[15] Nitisasmito, Alex S., 2000, manajemen personalia manajemen sumber daya manusia, Ghalia Indonesia, Jakarta.

[16] Ratminto \& Atik Septi Winarsih, 2015, manajemen pelayanan, Pustaka Pelajar, Yogyakarta.

[17] Rivai Veitshal, 2004, manajemen sumber daya manusia untuk perusahaan, dari teori ke praktek, PT. Raja Grafindo Persada, Jakarta.

[18] Sedarmayanti, 200I, sumber daya manusia dan produktivitas kerja, Mandar Maju Bandung.

[19] Sugiyono, 2005, metode penelitian bisnis, CV. Alfabeta, Bandung. [20] Bandung.
2015, metode penelitian kombinasi, CV. Alfabeta 
[21] Soehartono, 2004, pengaruh gaya kepemimpinan, motivasi, dan kemampuan kerja terhadap kinerja pegawai sekertaris daerah kabupaten Rembang, Universitas Diponegoro, Semarang.

[22] Sthepen P. Robbin, 200I, perilaku organisasi, konsep,kontroversi, dan aplikasi, Prenhalindo, Jakarta.

[23] The Liang Gie, 1993, ensiklopedia administrasi , Gunung Agung, Jakarta.

[24] Winardi, 2000, teori organisasi dan pengorganisasian, Rajawali Pers, Jakarta.

[25] Zainuddin Samad,2016, birokrasi dalam pelayanan publik, Ombak, Anggota Okapi, Yogyakarta.

[26] Magistra, 74 Th.XXII,20I0, Analisis Pengaruh Kepemimpinan dan Budaya Kerja dengan motivasi sebagai variable intervening terhadap kinerja karyawan di kantor pertanahan kebumen.

[27] http://www.slideshare.net/fitrianajinne/budaya-organisasi-danbudaya-kerja

[28] http://kuliahkomunikasi.blogspot.co.id/2008/I I/teorimotivasiMc .Clelland dan teori dua faktor Hezberg. 